J. Lake Sci.(湖泊科学), 2008, 20(6): 761-765

http://www.jlakes.org. E-mail: jlakes@niglas.ac.cn

(C)2008 by Journal of Lake Sciences

\title{
缓冲带径流污染物净化效果研究及其与草皮生物量的相关性*
}

\author{
吴建强，黄沈发，吴 健，熊丽君 \\ (上海市环境科学研究院, 上海 200233)
}

摘 要: 利用自行设计的实验装置和 5 种土著草皮构建草皮缓冲带, 模拟上海地区农业面源污染和降雨特征, 进行缓冲带污染物 净化效果和草皮生物量监测实验研究. 结果表明, 草皮缓冲带对径流污染物质的净化效果明显高于空白对照, 百慕大实验带 SS 平均截留率最高, 达到 $74 \%$; 白花三叶草 TN、TP 去除率最高, 分别为 $28 \%$ 和 $25 \%$; 黑麦草受高温的影响, 污染物净化效 果最差. 5 种草皮中, 百慕大和白花三叶草生物量最大, 栽种当年 9 月份, 两者地上部分的生物量鲜重分别为 $6.14 \mathrm{~kg} / \mathrm{m}^{2}$ 和 $6.49 \mathrm{~kg} / \mathrm{m}^{2}$; 百慕大生长速度最快, 9 月份生物量几乎达到 5 月份的 6 倍; 草皮生物量的增加明显提高了缓冲带对径流污染物的 去除效果, 生物量与径流 SS 去除率呈显著线性相关关系.

关键词：缓冲带; 净化效果; 草皮; 生物量; 相关性

\section{Pollutant removal efficiency of sward buffers to runoff and the correlation with biomass}

WU Jianqiang, HUANG Shenfa, WU Jian \& XIONG Lijun

(Shanghai Academy of Environmental Sciences, Shanghai 200233, P.R.China)

Abstract: To examine the pollutant removal efficiency of different sward buffers to runoff and the correlation with biomass, 5 native grasses were selected to construct buffer strips and conduct an experiment under the simulation of agricultural non-point pollution and rainfall characteristics in Shanghai. The results showed: 1) the clarification efficiency to runoff of sward buffers was significantly better than the blank control, the SS average retention rate of Cynodon dactylon buffer strip was the highest, up to $74 \%$; 2) the TN and TP average removal rate of Trifolium repens buffer strip was the highest, up to $28 \%$ and $25 \%$; 3 ) the clarification efficiency of Lolium perenne buffer was the lowest because of the high temperature; 4) the aboveground biomass of C. dactylon was $6.14 \mathrm{~kg} / \mathrm{m}^{2}$, and $T$. repens was $6.49 \mathrm{~kg} / \mathrm{m}^{2}$, higher than the other species; 5) the growth rate of $C$. dactylon was the fastest, whose biomass in September was almost as six times higher as in May; 6) the clarification efficiency of the sward was increased with higher biomass, there was a significant linear correlation between sward biomass and SS removal efficiency.

Keywords: Buffer strips; clarification effect; sward; biomass; correlation

缓冲带(Buffer strips)是指利用永久性植被拦截污染物或有害物质的条带状、受保护的土地 ${ }^{[1-5]}$. 人们 通常所指的缓冲带是植物缓冲带, 它构建于河流、湖泊岸边, 能有效地滞缓地表径流的速度, 截留径流中 的污染物质，保护水体水质和水生态系统不受侵害 ${ }^{[6-12]}$.

植物在缓冲带污染物净化作用中所起的重要作用是众所周知的, 通常认为, 生长浓密、迅速且耐污 能力强的草皮比其他植被拦截地表径流污染物质的能力要强 ${ }^{[13]}$. 通过选择上海地区常见的 5 种草皮种类, 利用自行设计的实验装置开展了缓冲带面源污染防治实验研究，旨在对比和分析草皮种类和生物量变化 对缓冲带污染物净化效果的影响，为上海地区缓冲带建设提供借鉴依据.

* 上海市科学技术委员会科研计划项目(04DZ12032)资助. 2007-11-28 收稿; 2008-03-18 收修改稿. 吴建强, 男, 1977 年生, 硕士, 工程师; E-mail: wujq@saes.sh.cn. 


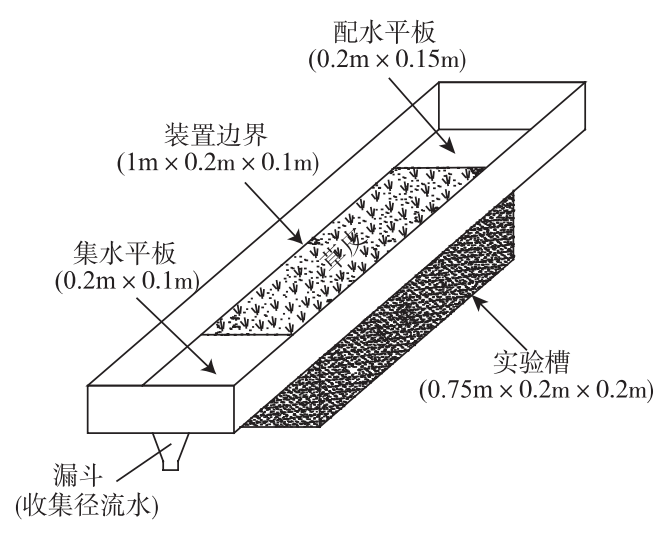

图 1 实验槽设计示意图

Fig.1 Tray design for laboratory test

\section{1 材料与方法}

\section{1 实验装置}

实验装置由钢化玻璃实验槽和不锈钢托架组成， 前端设置配水平板，后端设置集水平板和漏斗以收集 径流水(图 1). 实验槽置于托架之上, 设计坡度为 $4 \%$.

\section{2 基质与植被}

1.2.1 基质 取自苏州河上游东风港坡岸，土质类型主 要为青紫泥和沟干泥, 质地略显粘重.

1.2.2 植被 选用上海地区常见的 5 种多年生草皮植物, 百 慕大(Cynodon dactylon)、高羊茅(Festuca Arundinacea)、白 花三叶草(Trifolium repens)、黑麦草(Lolium perenne)和马蹄 金(Dichondra repens), 于 2005 年 3 月栽种.

\section{3 实验方法}

根据上海地区农业面源污染特征 ${ }^{[14-15]}$ ，人工配置

污水, 模拟上海地区降雨时产生的汇流过程和雨量开展实验研究.

1.3.1 降雨量和降雨历时 上海地区年均降雨量 $1104.4 \mathrm{~mm}$, 降雨天数 $130 \mathrm{~d}$ 左右, 主要集中在 5-10月的汛 期，实验模拟易产生地表径流的汛期典型工况(降雨历时 45-60min, 降雨量 30mm)开展研究.

1.3.2 污水配置 采用碳酸氢铵、过磷酸钲和泥土颗粒配制污水，主要模拟面源污染中的氮、磷和 SS 污染 物质.

1.3.3 监测方法 实验从 2005 年 5 月开始, 10 月结束, 每月 1 次, 共 6 次. 检测 SS、TN、TP. 实验分析方 法参照《水和废水监测分析方法》 ${ }^{[16]}$.

1.3.4 径流水取样方法 实验模拟降雨于前部配水平板，污水经过平板流人实验槽，一部分污水渗流进人 土壤后从底部小孔流出，另外一部分形成表面径流后从集水平板和漏斗流出，待形成稳定表面径流后从 漏斗处采集径流水样.

1.3.5 生物量取样方法 采用重量样方取样法 ${ }^{[17]}$, 沿实验槽长度方向平均取 3 个点, 每个点面积 $6 \mathrm{~cm} \times 6 \mathrm{~cm}$, 称重地上部分生物量, 取 3 点平均值然后换算为单位面积 $\left(1 \mathrm{~m}^{2}\right)$ 地上部分草皮生物量. 生物量计量分为鲜 重和干重, 取样之后立即用分析天平称重得到鲜重, 样品在恒温 $85^{\circ} \mathrm{C}$ 烘箱内烘干 $24 \mathrm{~h}$ 称重得干重. 实验 期间共取样 3 次, 分别是 5 月、 7 月和 9 月.

\section{2 结果与讨论}

\section{1 缓冲带径流污染物净化效果}

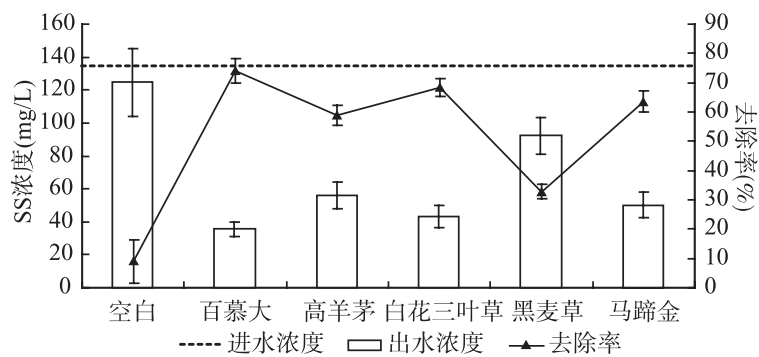

图 2 不同草皮缓冲带径流 SS 进出水浓度及去除率

Fig.2 The SS concentration of influent and effluent and it's removal efficiency to runoff water in different sward buffers
2.1.1 径流 SS 截留效果 6 次实验各缓冲带进 出水 $\mathrm{SS}$ 平均浓度和去除率如图 2 所示. 在进 水 $\mathrm{SS}$ 平均浓度为 $137 \mathrm{mg} / \mathrm{L}$ 的条件下, 百慕 大缓冲带出水最稳定, 平均浓度也最低, 仅 为 $38 \mathrm{mg} / \mathrm{L}$, 去除率达到 74\%, 其次为白花三 叶草、马蹄金、高羊茅、黑麦草和空白对照, $\mathrm{SS}$ 截留率分别为 $68 \%$ 、64\%、59\%、32\%和 8\%(图 2). 究其原因，在实验期间，暖季型草 皮百慕大生长有浓密的匍匐茎, 覆盖于整个 土壤表层，能充分拦截径流中悬浮物质，而 黑麦草则由于在高温状态下长势很差，从而 降低了其截留污染物质的能力. 相对于空白 
对照而言，草皮的存在能明显提高缓冲带对径流污染物质的截留效果.

2.1.2 径流 TN 净化效果 草皮缓冲带对径流 TN 的净化效果不明显, 主要是因为径流水在缓冲带表面流过, 时 间较短, 植物的吸收和微生物的降解功能没能得到体现. 对比 6 个实验带, 在进水 $\mathrm{TN}$ 平均浓度为 $15.6 \mathrm{mg} / \mathrm{L}$ 的 条件下，白花三叶草缓冲带径流出水最稳定，平均浓度也最低，为 $11.50 \mathrm{mg} / \mathrm{L}$ ，去除率为到 $28 \%$, 其次为百 慕大、高羊茅、马蹄金、黑麦草和空白对照，其中黑麦草的去除率仅为 $10 \%$, 空白对照则为 $6 \%$ (图 3a).

2.1.3 径流 TP 净化效果 各缓冲带对径流水中 TP 的净化效果基本同于 $\mathrm{TN}$, 效果不明显, 甚至比 TN 净化 效果更差. 在进水平均 TP 浓度为 $0.8 \mathrm{mg} / \mathrm{L}$ 的条件下, 各缓冲带径流出水 TP 去除效果对比是白花三叶草> 百慕大 $>$ 马蹄金 $>$ 高羊茅>黑麦草>空白对照，去除率分别为 $25 \% 、 21 \% 、 18 \% 、 17 \% 、 11 \%$ 和 5\%(图 3b).

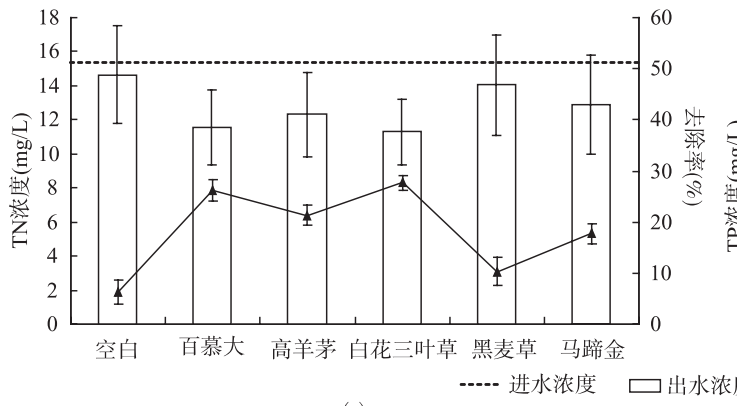

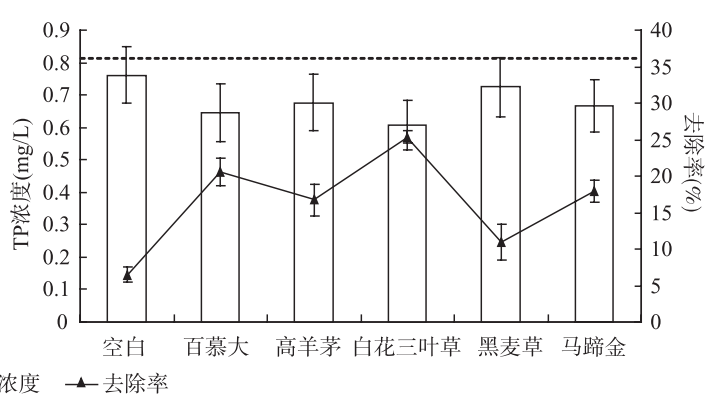

(b)

图 3 不同草皮缓冲带径流 TN(a)和 TP(b)进出水浓度及去除率

Fig.3 The TN(a) and TP (b)concentrations of influent and effluent and it's removal efficiency to runoff water in different sward buffers

\section{2 草皮生物量与净化效果相关性分析}

3 个月的污染物监测结果见表 1 .

表 1 生物量和污染物去除效率变化

Tab.1 The changes of biomass and contamination removal efficiency

\begin{tabular}{ccccccc}
\hline 草皮类型 & $\begin{array}{c}\text { 时间 } \\
(\text { 月 })\end{array}$ & $\begin{array}{c}\text { 鲜重 } \\
\left(\mathrm{kg} / \mathrm{m}^{2}\right)\end{array}$ & $\begin{array}{c}\text { 干重 } \\
\left(\mathrm{kg} / \mathrm{m}^{2}\right)\end{array}$ & $\begin{array}{c}\text { 径流 } \mathrm{SS} \\
\text { 去除率 }(\%)\end{array}$ & $\begin{array}{c}\text { 径流 } \mathrm{TN} \\
\text { 去除率 }(\%)\end{array}$ & $\begin{array}{c}\text { 径流 TP } \\
\text { 去除率(\%) }\end{array}$ \\
\hline 百慕大 & 5 & 1.13 & 0.40 & 58.52 & 20.92 & 13.79 \\
& 7 & 5.33 & 2.09 & 69.75 & 24.94 & 20.75 \\
高羊茅 & 9 & 6.14 & 2.53 & 78.62 & 25.00 & 23.57 \\
& 5 & 2.68 & 0.64 & 53.61 & 25.00 & 12.07 \\
白花三叶草 & 7 & 1.48 & 0.35 & 44.72 & 16.85 & 10.84 \\
& 9 & 3.84 & 0.92 & 62.61 & 18.54 & 23.69 \\
& 5 & 3.56 & 0.57 & 56.58 & 20.50 & 23.97 \\
黑麦草 & 7 & 6.24 & 1.07 & 67.64 & 27.46 & 26.24 \\
& 9 & 6.49 & 1.26 & 73.37 & 30.36 & 26.31 \\
& 5 & 0.95 & 0.27 & 45.36 & 11.51 & 6.90 \\
马蹄金 & 7 & - & - & 17.17 & -3.43 & -2.89 \\
& 9 & 0.77 & 0.24 & 28.66 & 11.89 & 18.30 \\
& 5 & 1.21 & 0.21 & 57.42 & 13.49 & 14.87 \\
& 7 & 2.22 & 0.40 & 63.43 & 18.95 & 17.24 \\
& 9 & 2.54 & 0.49 & 68.16 & 24.46 & 18.06 \\
\hline
\end{tabular}




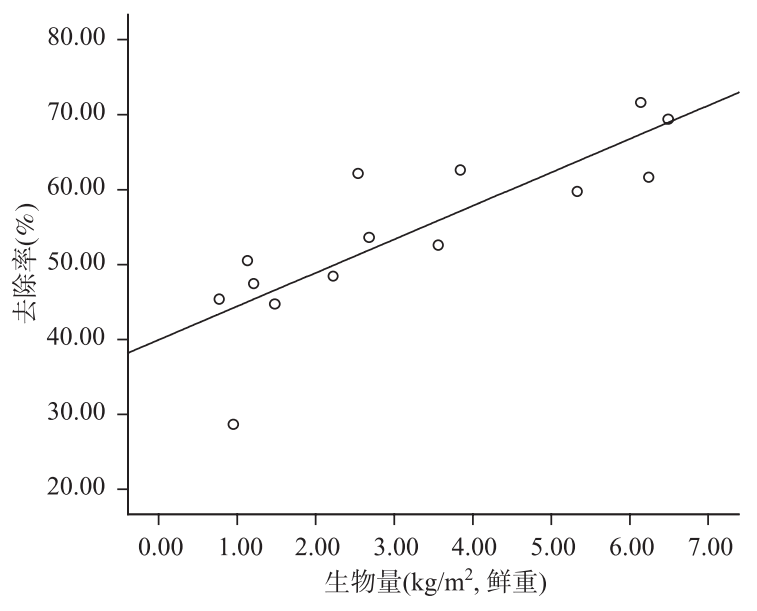

图 4 草皮生物量与 $\mathrm{SS}$ 去除率相关关系

Fig.4 Correlation of sward biomass and SS removal efficiency

采用 SPSS 统计软件对生物量和 SS 去除 率进行相关性分析, 得出生物量与 SS 去除率 的关系如图 4. 根据相关分析结果, 在 0.99 置 信度 $(P<0.01)$ 下两者的相关系数为 0.83 , 说明 生物量与 $\mathrm{SS}$ 去除率呈显著线性相关，两者线 性拟合结果如下:

$E=4.468 B I O+39.948\left(n=14, R^{2}=0.83, P<0.01\right)$ 式中: $E$ 为 $\mathrm{SS}$ 去除率 $(\%) ; B I O$ 为生物量, $\left(\mathrm{kg} / \mathrm{m}^{2}\right.$, 鲜重 $) ; n$ 为样本数; $R^{2}$ 为相关系数; $P$ 为检验的显著性水平.

\section{3 讨论}

植被的存在是缓冲带的特点所在，植被 通过自身吸收、输送溶解氧、为微生物提供 栖息地、疏松土壤、滞缓径流、调节微气候 等功能来实现其对滨岸缓冲带面源污染防治 和生境改善作用的巨大贡献 ${ }^{[18]}$. 研究发现 ${ }^{[19]}$, 草本类植物由于其生长密集、覆盖于地表等特点, 能最有效地滞缓径流, 截留地表径流污染物和降解、 吸收沉积污染物质. 虽然缓冲带技术已经在国外研究实践中得到广泛应用并取得了一致公认的效果, 但 国内对其研究起步较晚, 相关的研究工作主要停留在陆域土地利用、规划设计、景观功能和植被重建等 方面 ${ }^{[20-21]}$.

本文根据上海地区大量农业面源污染未得到有效控制的实际情况，开展不同草本植被缓冲带面源污染 防治实验研究，旨在为今后缓冲带在上海及类似地区的实际应用提供基础依据. 实验研究发现，草本类植 物能有效截留地表径流中的悬浮物质，而且草皮生物量与缓冲带径流污染物质去除效果具有明显相关性， 生物量越大, 去除率越高, 以本实验研究 SS 监测结果为例, 草皮生物量与 SS 去除率呈显著线性相关关系. 本实验选用的 5 种草皮, 百慕大和白花三叶草生物量增长最快, 其实验带污染物去除效果也最好. 而对于冷 季型草皮高羊茅和黑麦草，在高温季节生长不好，直接影响缓冲带的污染物净化效果，并且植物的枯萎 腐烂还能导致营养物质重新回到水体中. 草皮缓冲带对径流水中氮、磷营养物质降解效果不明显, 分析 原因可能主要有两个方面：一是径流水直接从缓冲带表层流过，时间较短，植物吸收作用不明显; 二是 缓冲带构建时间较短，未形成稳定的微生物群落，对氮、磷的去除作用简单依靠过滤、截留等物理作用， 效果不佳.

总体而言，在河道和湖泊周围岸坡建设草皮缓冲带，以此来防止降雨径流对泥土的冲刷，削减进人 水体的地表悬浮物质总量是行之有效的手段. 因为上海地区雨量集中在 5-10 月汛期, 农业面源污染物随 径流流失也主要发生在这一时期，所以实验周期也是 5-10 月。但是，不同季节温度的差异、不同地区土 壤条件差异以及不同时间跨度植被生长的差异等都会对缓冲带面源污染防治的功能产生较大的影响，因 此, 今后还需要在这些方面开展深人研究, 以提高缓冲带的实际推广应用价值.

\section{3 结论}

(1)草皮缓冲带能有效截留径流水中的悬浮物质，在进水 SS 平均浓度为 $137 \mathrm{mg} / \mathrm{L}$ 的条件下, 5 种草皮 缓冲带的 SS 截留效果排序为百慕大>白花三叶草>马蹄金>高羊茅>黑麦草>空白对照，截留率分别为 $74 \%$, $68 \% 、 64 \% 、 59 \% 、 32 \%$ 和 $8 \%$.

(2)草皮缓冲带对径流水中的氮、磷营养物质净化效果不明显，白花三叶草缓冲带对 TN、TP 的去除 率最高，分别为 $28 \%$ 和 $25 \%$. 黑麦草由于夏季高温条件下地上部分出现枯萎现象，导致其实验带径流出 水浓度反而高于进水.

(3)百慕大和白花三叶草生物量最大, 9 月份两者的地上部分生物量鲜重分别达到了 $6.14 \mathrm{~kg} / \mathrm{m}^{2}$ 和 
$6.49 \mathrm{~kg} / \mathrm{m}^{2}$; 百慕大生长速度最快, 其 9 月份生物量几乎达到 5 月份的 6 倍. 缓冲带径流水污染物净化效果 随着草皮生物量的增加显著提高, SS 截留率与草皮生物量呈显著线性相关关系.

\section{4 参考文献}

[1] Washington DC. Buffer Strips: common sense conservation. Natural Resources Conservation Service, USDA, 1998.

[2] David LC. Principles of planning and establishment of buffer zones. Ecological Engineering, 2005, 24: 433-439.

[3] Tara R, Stephen R. Comparisons of P-yield, riparian buffer strips, and land cover in six agricultural watersheds. Ecosystems, 2002, 5: 568-577.

[4] Das C, Capehart WJ, Mott HV et al. Assessing regional impacts of conservation reserve program-type grass buffer strips on sediment load reduction from cultivated lands. Journal of Soil and Water Conservation, 2004, 59(4): 134-142.

[5] 倪九派, 傅 涛, 卢玉东等. 缓冲带在农业非点源污染防治中的应用. 环境污染与防治, 2002, 24(4): 229-231.

[6] 陈小华, 李小平. 河道生态护坡关键技术及其生态功能. 生态学报, 2007, 27(3): 1168-1175.

[7] 卢宝倩, 黄沈发, 唐 浩. 滨岸缓冲带农业面源污染控制技术研究进展. 水资源保护, 2007, 3(增刊): 7-9.

[8] 张建春, 彭补拙. 河岸带研究及其退化生态系统的恢复与重建. 生态学报, 2003, 23(1): 56-63.

[9]＼cjkstart杨海军，张化永，赵亚楠等. 用芦苇恢复受损河岸生态系统的工程化方法. 生态学杂志, 2005, 24(2): 214-216.

[10] Greenway M. Suitability of macrophytes for nutrient removal from surface flow constructed wetlands receiving secondary treated sewage effluent in Queensland, Australia. Water Science and Technology, 2003, 48(2): 121-128.

[11] 钟 勇. 美国水土保持中的缓冲带技术. 中国水利, 2004, 10: 63-65.

[12] Venkatachalam Anbumozhi, Jay Radhakrishnan, Eiji Yamaji. Impact of riparian buffer zones on water quality and associated management considerations. Ecological Engineering, 2005, 24: 517-523.

[13] Susan MS. Movement of forest birds across river and clearcut edges of varying riparian buffer strip widths. Forest Ecology and Management, 2006, 223: 190-199.

[14] 黄沈发, 陆贻通, 沈根祥等.上海郊区旱作农田氮素流失研究. 农村生态环境, 2005, 21(2): 50-53.

[15] 黄沈发, 沈根祥, 唐 浩等. 上海郊区稻田氮素流失研究. 环境污染与防治, 2005, 27(9): 651-654.

[16] 国家环境保护局编. 水和废水监测分析方法(第III版). 北京: 中国环境科学出版社, 1989.

[17] 吴千红. 生态学野外及实验室实验手册. 北京: 科学出版社, 1986.

[18] 范小华, 谢德体, 魏朝富. 河岸带生态系统管理模型研究进展. 中国农学通报, 2006, (22): 277-282.

[19] Anna Lloyda, Bradley Law, Ross Goldingay. Bat activity on riparian zones and upper slopes in Australian timber production forests and the effectiveness of riparian buffers. Biological Conservation, 2006, 129: 207-220.

[20] 潘响亮, 邓 伟. 农业流域河岸缓冲区研究综述. 农业环境科学学报, 2003, 22(2): 244-247.

[21] 邓红兵, 王青春, 王庆礼等. 河岸植被缓冲带与河岸带管理. 应用生态学报, 2001, 12(6): 951-954. 